\title{
STUDY OF THE USE OF BIOMASS INSIDE THE PELLETS UNDER INDURATION FURNACE PROCESS CONDITIONS*
}

\author{
Flavia de Paula Vitoretti ${ }^{1}$ \\ José Adilson de Castro² \\ Bruno Chaboli Gambarato 3 \\ Maria Carolina dos Santos Freitas ${ }^{4}$
}

\begin{abstract}
Pelletizing of iron ore fines is an important process used to produce high quality of raw materials for the subsequent reduction processes in the ironmaking industries. The process involves the production of green pellets and subsequent induration on a traveling grate furnace to promote inner partial melt and agglomeration which confer physical and metallurgical proprieties appropriated to the subsequent reduction processes. The pellets are produced with addition of charcoal to improve efficiency in the reduction processes. The lignin coal from sugarcane straw is an alternative source to replace the charcoal or coke in the self reduction of pellets. This work focused on the influence of biomass on the chemical kinetics parameters inner agglomerate pellet structure under industrial process conditions of the travelling grate furnace due hot gas flows within the pellets.
\end{abstract}

Keywords: Pellets; Agglomeration; Biomass; Lignin.

1 Chemical Engineering, Master degree, P.hD. Studenty, PostGraduate Program on Metallurgical Engineer. UFF/ UniFOA, Volta Redonda, RJ, Brasil.

2 Metallurgical Engineering, P.hD., Professor, PostGraduate Program on Metallurgical Engineer. UFF, Volta Redonda, RJ, Brasil.

3 Chemical Engineering, Master degree, P.hD. Studenty, PostGraduate Program on Chemical Engineer. USP/ UniFOA, Lorena, SP, Brasil.

4 Mechanical Engineering, P.hD., Professor, Mechanical Department, UFF, Volta Redonda, RJ, Brasil.

* Contribuição técnica ao $44^{\circ}$ Seminário de Redução de Minério de Ferro e Matérias-primas, $15^{\circ}$ Simpósio Brasileiro de Minério de Ferro e $2^{\circ}$ Simpósio Brasileiro de Aglomeração de Minério de Ferro, 15 a 18 de setembro de 2014, Belo Horizonte, MG, Brasil. 


\section{INTRODUTION}

The generation of fines in ironmaking industries with environmental conditions has motivated the development of the use of recycling materials. Therefore, the use of biomass as carbon source has contributed to the development of processes. The pelletizing is an agglomeration process to produce raw materials suitable for using in blast furnace and reduction processes. This process involves two steps, the "green pellets" formation with the addition of binder to enhance agglomeration phenomena, and then the pellets follow to induration furnace, to attain mechanical resistance and appropriate metallurgical characteristics required in the ironmaking facilities. The induration process using travelling grate can be divided into 4 different stages: drying, heating, firing and cooling zones [1]. The drying and heating zones ensure that water and volatile are removed and do not interfere with subsequent reactions zones. In the firing zone occurs a partial melting to acquire mechanical strength through the sintering process of particles. Several researches have studied the kinetics of drying of the pellets and the reduction of iron ore by carbon involving chemical reactions and mass transfer between solids. The lignin was obtained by soda pulp $(1 \% \mathrm{~m} / \mathrm{v})$ of sugar cane straw for approximately $1 \mathrm{~h}$ at $100^{\circ} \mathrm{C}$ and precipitated in acidic. The lignin thermal conversion to coal was realized in a furnace under inert atmosphere at $400^{\circ} \mathrm{C}$ for $2 \mathrm{~h}$. The aim of this work is thermalgravimetric analysis to determinate the parameters kinetic considering the effects of temperature, heating rate, pellet composition and inert gas flow rate.

\section{MATERIALS AND METHODS [2-6]}

Reaction kinetics analysis in non-isothermal processes has been the subject of a large number of studies. However in this case the greatest difficulty is to perform the experiments the influence of temperature variation in the weight loss as it involves continuous measurement of the mass change as a function of temperature and time. Therefore, the TGA is an equipment that allows this kind of analysis. For this study, the TGA / DSC SDT Q600 model from TA Instruments with a variation in the heating rate of the pellets of 5,10 and $20^{\circ} \mathrm{C} / \mathrm{min}$ was used. And the samples thermodegradation was verified in each case, the total loss of mass by a temperature gradient and activation energy.

\subsection{Kinetic}

The thermogravimetric data was used to study the kinetics of thermodegradation of the pellets. Fundamentally, the kinetic model follows the Arrhenius equation:

$$
k(T)=k_{o} e^{-E / R T}
$$

Where $k$ is the rate reaction, $k_{o}$ is exponential factor, $E$ is activation energy, $R$ is the gas constant and $T$ is temperature.

The rate equation of a chemical reaction is written generically as:

$$
r=k(1-\alpha)^{n}
$$

Where $\alpha$ is the fraction reacted and $n$ is reaction order. Thus, the reaction rate equation, which relates $\alpha$ with time is given by:

$$
-\frac{d \alpha}{d t}=k_{0} e^{-E / R T}(1-\alpha)^{n}
$$

\footnotetext{
* Contribuição técnica ao $44^{\circ}$ Seminário de Redução de Minério de Ferro e Matérias-primas, $15^{\circ}$ Simpósio Brasileiro de Minério de Ferro e $2^{\circ}$ Simpósio Brasileiro de Aglomeração de Minério de Ferro, 15 a 18 de setembro de 2014, Belo Horizonte, MG, Brasil.
} 
Since, over time, the reaction temperature increases to a $\beta=\frac{d T}{d t}\left[{ }^{\circ} \mathrm{C} \cdot \mathrm{min}^{-1}\right]$ rate, Equation (3) can be rewritten as

$$
-\beta \frac{d \alpha}{d T}=k_{0} e^{-E / R T}(1-\alpha)^{n}
$$

Rearranging of Equation (4),

$$
-\int_{0}^{1} \frac{d \alpha}{(1-\alpha)^{n}}=\frac{k_{0}}{\beta} \int_{T_{0}}^{T} e^{-E / R T} d T
$$

Calling the left side of Equation (5) $\mathrm{G}(\alpha)$, and analytic solutions are given by equations (6) and (7).

$$
\begin{array}{r}
n=1: G(\alpha)=-\ln (1-\alpha) \\
n \neq 1: G(\alpha)=\frac{1-(1-\alpha)^{1-n}}{1-n}
\end{array}
$$

And so, the linearized model is:

$$
\ln \frac{\beta G(\alpha)}{T^{2}}=\ln \frac{k_{0} R}{E}-\frac{E}{R T}
$$

The parameters obtained from linear regression allow then determine the values of activation energy and pre-exponential factor. The kinetic parameters of the thermodegradation, coupled with mass transfer mechanisms provide important information for the development and optimization of thermochemical information systems.

\section{RESULTS AND DISCUSSIONS}

Studies of this work are the experimental analysis of kinetic phenomena of an iron ore pellet subjected to different heating rates, raw material for the manufacture of steel. The analyzes involve measurements of mass loss of the samples in the variation of temperature and time. Therefore, will be presented and discussed the main issues arising from the kinetic analysis of experimental samples.

The chemical composition of the pellets is given in Table 1 and particles size distribution of the "pellets feed" and lignin coal are presented in Table 2 . The raw materials of the pellets are given in Table 3 and the proximate analyses of the lignin coal materials after thermal treatment are showed in Table 4.

Tabela 1. Chemical Composition of the "pellet feed

\begin{tabular}{cccccccc}
\hline $\mathrm{Fe}_{2} \mathrm{O}_{3}$ & $\mathrm{FeO}$ & $\mathrm{SiO}_{2}$ & $\mathrm{Al}_{2} \mathrm{O}_{3}$ & $\mathrm{CaO}$ & $\mathrm{MgO}$ & $\mathrm{P}$ & LOI $^{*}$ \\
\hline $93,80 \%$ & $1,28 \%$ & $1,53 \%$ & $0,42 \%$ & $0,12 \%$ & $0,05 \%$ & $0,07 \%$ & $2,73 \%$ \\
\hline 'LOI - Lost Of Ignition & & & & & &
\end{tabular}

The experimental system where the pellet was placed inside of the sample beam, position (1), and the position (2) is the reference beam. The furnace is heated electrically to $1200^{\circ} \mathrm{C}$, under a inert atmosphere of $\mathrm{N}_{2}$. Heating rates : $5^{\circ} \mathrm{C} / \mathrm{min}$, $10^{\circ} \mathrm{C} / \mathrm{min}$ e $20^{\circ} \mathrm{C} / \mathrm{min}$ with inert gas flowrate of $100 \mathrm{ml} / \mathrm{min}$.

\footnotetext{
* Contribuição técnica ao 44 Seminário de Redução de Minério de Ferro e Matérias-primas, 15ㅇ Simpósio Brasileiro de Minério de Ferro e 2o Simpósio Brasileiro de Aglomeração de Minério de Ferro, 15 a 18 de setembro de 2014, Belo Horizonte, MG, Brasil.
} 
Table 2. Particle Size Distribution

\begin{tabular}{cccccc}
\hline & $\begin{array}{c}+150 \mu \mathrm{m} \\
(\# 100)\end{array}$ & $\begin{array}{c}+106 \mu \mathrm{m} \\
(\# 140)\end{array}$ & $\begin{array}{c}+75 \mu \mathrm{m} \\
(\# 200)\end{array}$ & $\begin{array}{c}+53 \mu \mathrm{m} \\
(\# 270)\end{array}$ & $\begin{array}{c}-53 \mu \mathrm{m} \\
\text { (bottom) }\end{array}$ \\
\hline $\begin{array}{c}\text { "pellet } \\
\text { feed" }\end{array}$ & $1,82 \%$ & $4,83 \%$ & $9,45 \%$ & $19,13 \%$ & $64,78 \%$ \\
\hline Lignin Coal & $0,0 \%$ & $0,0 \%$ & $0,0 \%$ & $0,1 \%$ & $99,9 \%$ \\
\hline
\end{tabular}

Table 3. Raw Materials of pellets

\begin{tabular}{ccc}
\hline Iron Ore & Lignin Coal & Binder \\
\hline $75,2 \%$ & $18,8 \%$ & $6 \%$ \\
\hline
\end{tabular}

Table 4. Analysis of the carboniferous materials

\begin{tabular}{ccccc}
\hline $\mathrm{C}$ & $\mathrm{H}$ & $\mathrm{N}$ & $\mathrm{S}$ & $\mathrm{O}$ \\
\hline $84,08 \%$ & $3,26 \%$ & $0,13 \%$ & $0,81 \%$ & $11,72 \%$ \\
\hline
\end{tabular}

The increase of the temperature and heating rate led to higher conversion rate. Figure 1 show loss of mass as a function of residence time, varying the temperature as a function of time. The pellets were under the different thermal conditions at according to Figure 1, with average mass and size of $170 \mathrm{mg}$ and $5 \mathrm{~mm}$ of diameter. The drying is a process highly endothermic and depends on the external temperature gradient.

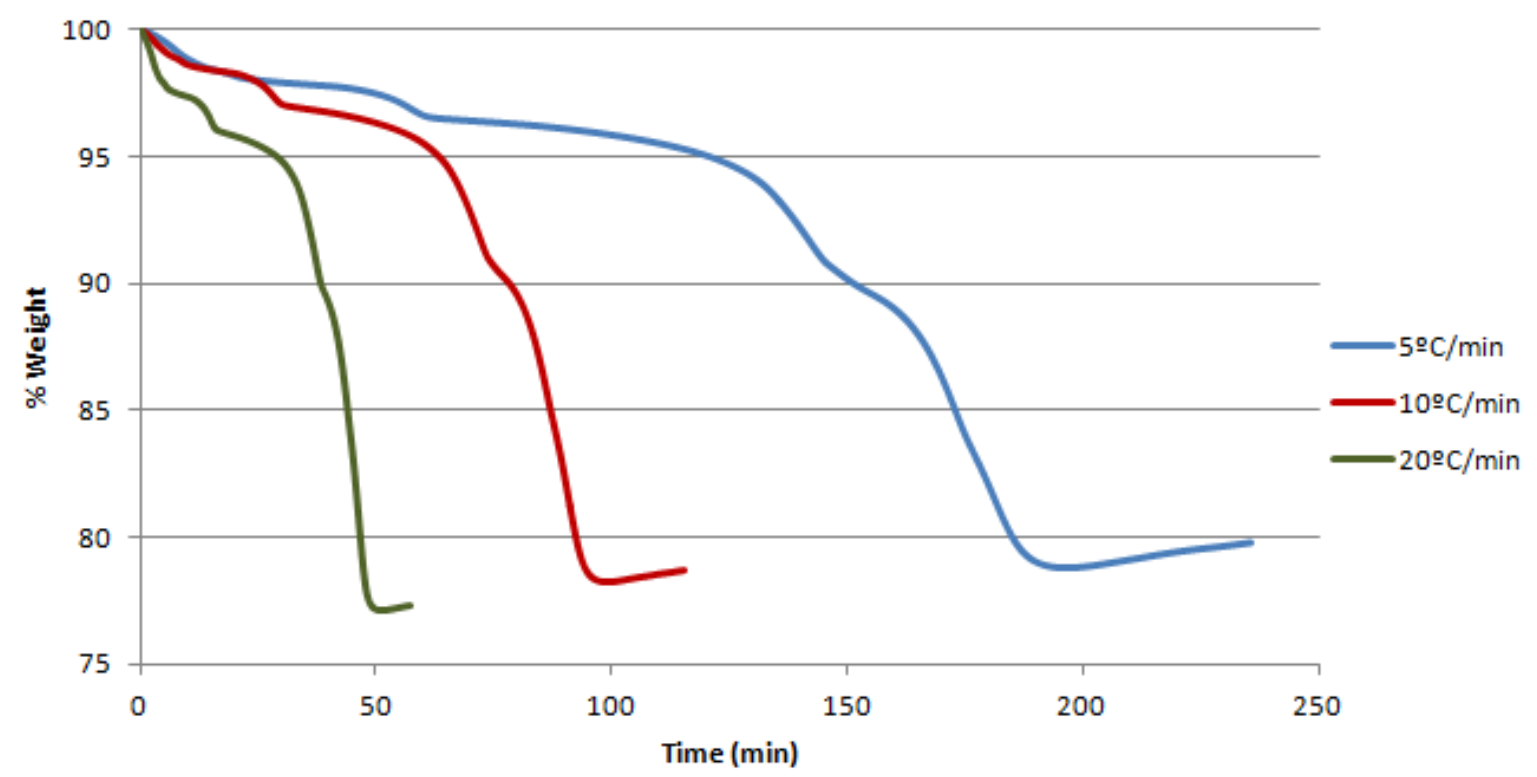

Figure 1. Mass variation according to Temperature for heating rate of $5^{\circ} \mathrm{C} / \mathrm{min} ; 10^{\circ} \mathrm{C} / \mathrm{min} ; 20^{\circ} \mathrm{C} / \mathrm{min}$.

Figure 2 shows the fractional reaction for differents heating rate for drying of the pellets.

\footnotetext{
* Contribuição técnica ao 44 Seminário de Redução de Minério de Ferro e Matérias-primas, $15^{\circ}$ Simpósio Brasileiro de Minério de Ferro e $2^{\circ}$ Simpósio Brasileiro de Aglomeração de Minério de Ferro, 15 a 18 de setembro de 2014, Belo Horizonte, MG, Brasil.
} 


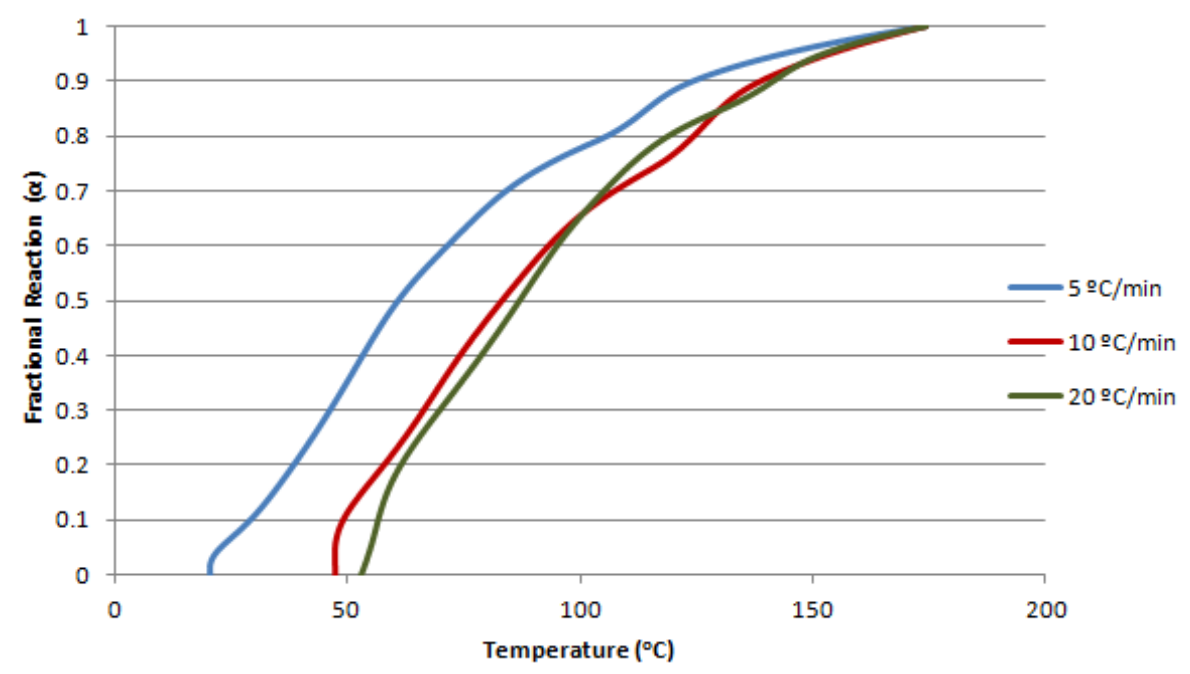

Figure 2. Fractional Reaction versus time for differents heating rates for Drying process.

It was observed that rate constants are affected by heating rate, higher temperature gradient improves the drying kinetic. In those conditions, the pellets are quickly soaked by the gas and a more uniform drying occurs. The drying process should be controlled so that there is no degradation of the pellets. High heating rates generate large internal vapor pressures. The Figure 3 shows the kinettic parameters to drying process to pellets with heating rate of 5,10 and $20^{\circ} \mathrm{C} / \mathrm{min}$.

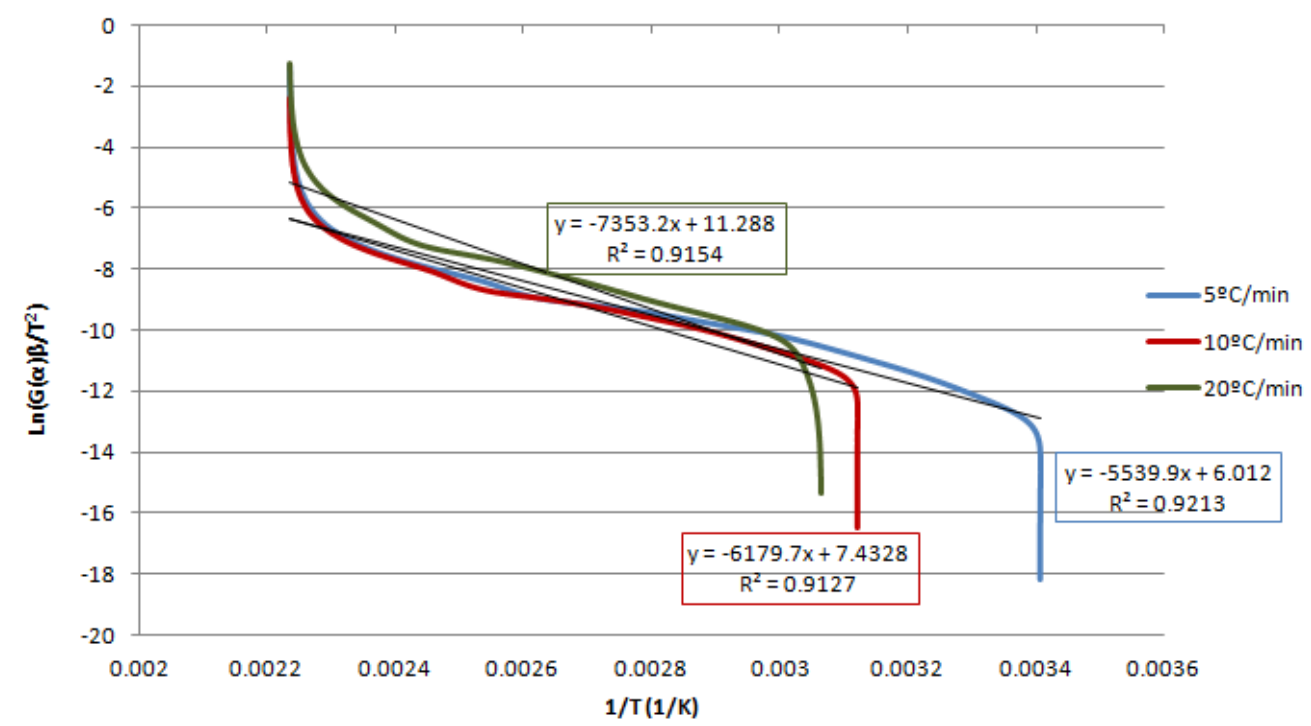

Figure 3. Arrhenius plot for rate constant according to temperature for drying process.

It was possible to calculate the activation energy and pre-exponential factor. For $5^{\circ} \mathrm{C} / \mathrm{min}$ rate $E=46,06 \mathrm{KJ} / \mathrm{mol}$ and $k_{0}=2,26 \times 10^{6} \mathrm{~s}^{-1}$. For $10^{\circ} \mathrm{C} / \mathrm{min} E=51,38 \mathrm{KJ} / \mathrm{mol}$ and $k_{o}=1,04 \times 10^{7} \mathrm{~s}^{-1}$ and to $20^{\circ} \mathrm{C} / \mathrm{min} \mathrm{E}=61,14 \mathrm{KJ} / \mathrm{mol}$ and $k_{o}=5,87 \times 10^{8} \mathrm{~s}^{-1}$.

Figure 4 shows the fractional reaction for reduction of iron ore by $\mathrm{CO} / \mathrm{CO}_{2}$ generated locally inside of the pellets according to gaseous intermediates of the reaction.

$$
\begin{gathered}
F e_{x} O_{y_{(s)}}+y C O_{(g)} \rightarrow x F e_{(s)}+y C O_{2(g)} \\
x C_{(s)}+x C O_{2(g)} \rightarrow 2 x C O_{(g)} \\
F e_{x} O_{y(s)}+x C_{(s)} \rightarrow x F e_{(s)}+(y-x) C O_{2(g)}+(2 x-y) C O_{(g)}
\end{gathered}
$$

* Contribuição técnica ao $44^{\circ}$ Seminário de Redução de Minério de Ferro e Matérias-primas, $15^{\circ}$ Simpósio Brasileiro de Minério de Ferro e $2^{\circ}$ Simpósio Brasileiro de Aglomeração de Minério de Ferro, 15 a 18 de setembro de 2014, Belo Horizonte, MG, Brasil. 


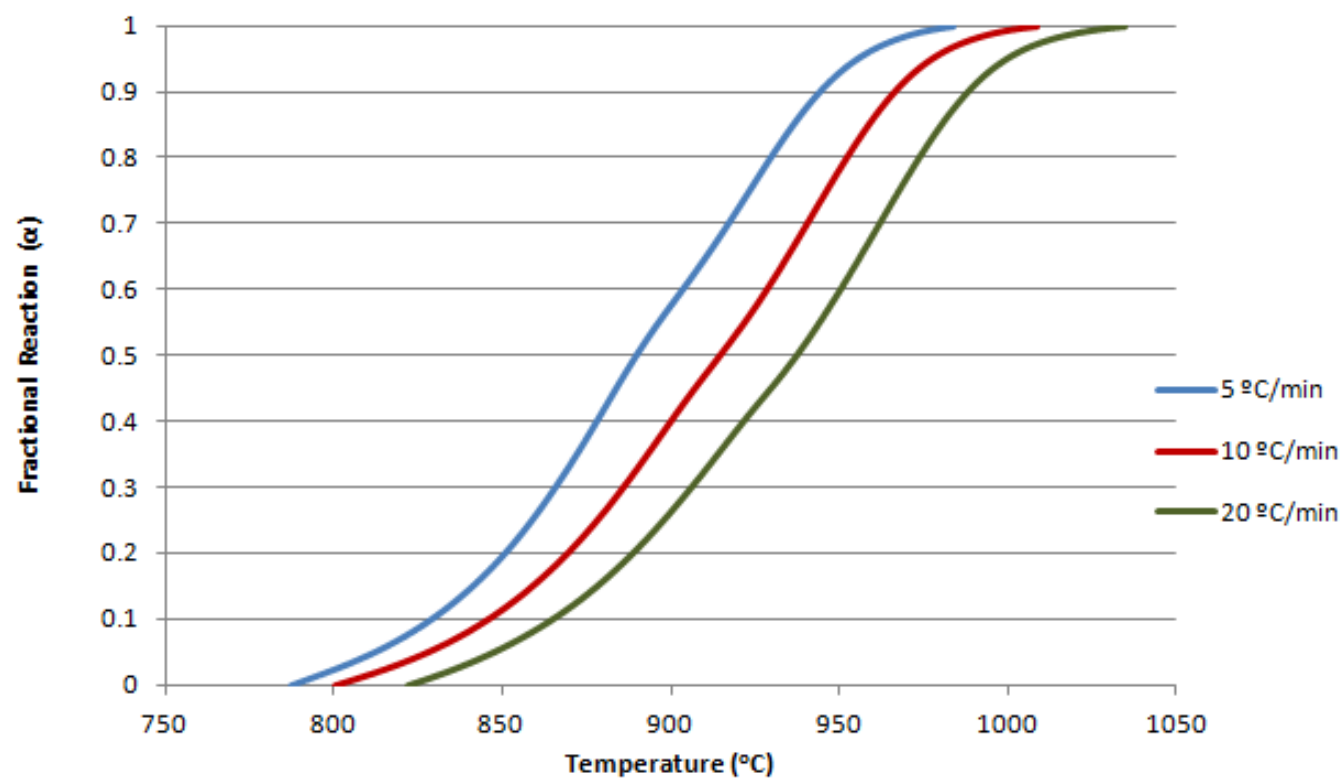

Figure 4. Fractional Reaction versus time for differents heating rates for Reduction process.

The reduction reaction is a highly endothermic reaction, especially the Bourdouard reaction. It was observed that thermal equilibrium was reached only at the end of the drying and reduction process.

Some authors have developed complex kinectics about drying and reduction of iron ore. It observed that most studies solve the rate constate in process isothermic.

In order to develop the analysis the kinetic of drying and partial self-reduction of iron ore pellets was possible determinated a rate constant of non-isothermic process. The Equation(8) shows the kinetic relation between temperature and residence time.

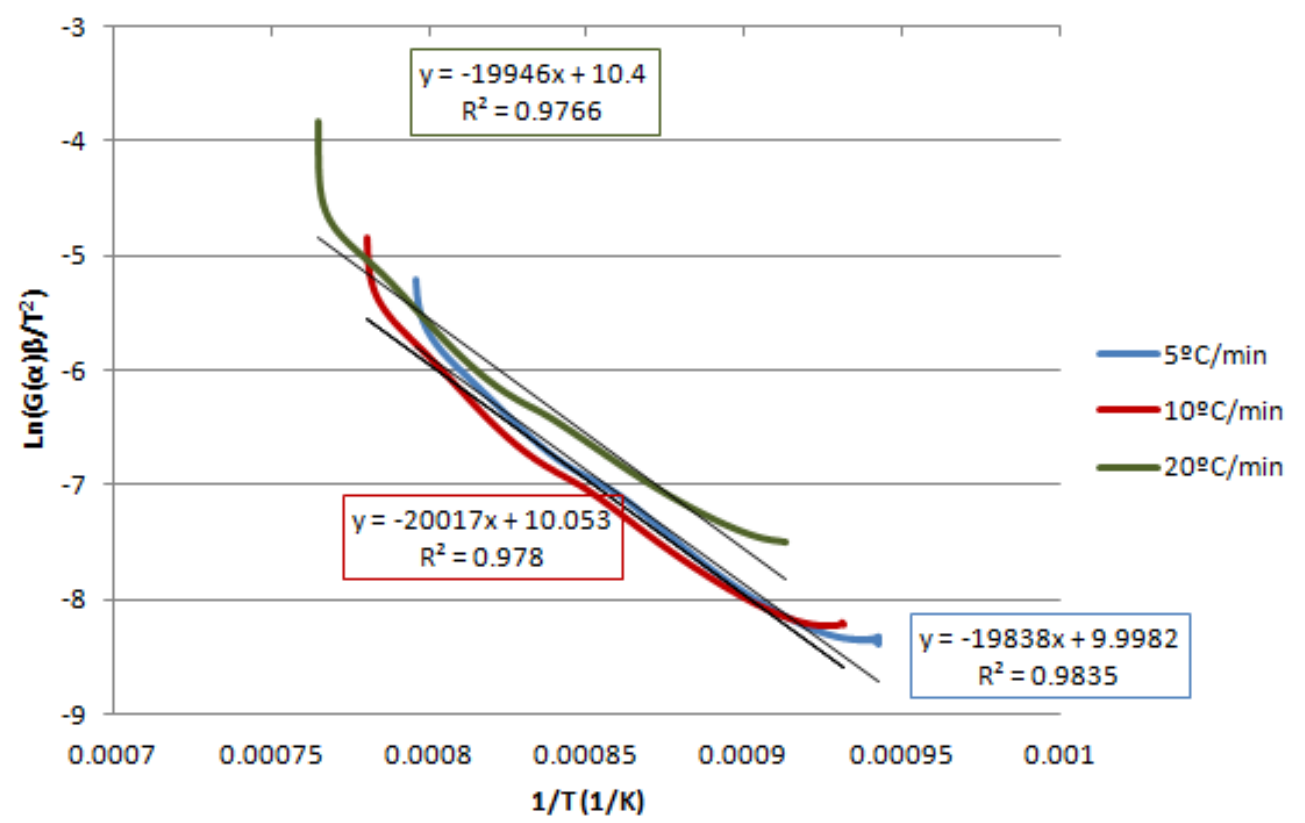

Figure 5. Arrhenius plot for rate constant according to temperature for reduction process.

* Contribuição técnica ao $44^{\circ}$ Seminário de Redução de Minério de Ferro e Matérias-primas, $15^{\circ}$ Simpósio Brasileiro de Minério de Ferro e $2^{\circ}$ Simpósio Brasileiro de Aglomeração de Minério de Ferro, 15 a 18 de setembro de 2014, Belo Horizonte, MG, Brasil. 


\section{CONCLUSIONS}

This work was able to predict the kinetic behaviour for drying and reduction of iron ore pellets with lignin coal in a non isothermal process. The activation energy at different heating rates was calculated. The kinetic for partial self-reduction investigated was also demonstrated and the activation energy for reduction process was about $165,166,4$ and $165,8 \mathrm{~kJ} / \mathrm{mol}$, for heating rates of 5,10 and $20^{\circ} \mathrm{C} / \mathrm{min}$ respectively. These results show that drying at a higher rate of heating is the best way to achieve an efficient evaporation of moisture inside of the pellet.

\section{Acknowledgment}

The research presented in this paper was conducted at the Federal Fluminense University (UFF), Metallurgical Engineer School (EEIMVR) and Centro Universitário de Volta Redonda (UNIFOA), Brazil. We would like to thank to CAPES and UFF and UNIFOA scholarship for master and Ph.D degree.

\section{REFERENCES}

1 Vitoretti FP, Castro JA. Study of the induration phenomena in single pellet to traveling grate furnace. Journal Materials Research and Technology, 2013

2 Araujo GM. Estudo da cinética de redução dos óxidos de ferro com a proposição de um novo aglomerado redutor [Ph.D Thesis]. Volta Redonda: Universidade Federal Fluminense; 2013.

3 Carvalho RJ, Netto PGQ, D'Abreu JC. Kinetic of Reduction of Composite Pellets Containing Iron Ore and Carbon. Canadian Metallurgical Quarterly, 1994; 33(3): 217-225 e 2(4): 315-322.

4 Levenspiel O. Chemical Reaction Engineering, $2^{\text {nd }}$ ed. John e Sons; 1972. p.357-373.

5 Mourão MB, Capocchi JDT. Rate of reduction of iron oxide in carbon-bearing pellets. Trans. Instn. Min. Metall. Sec. C, 1996;105:C190-C196.

6 Oyedun AO, Lam K-L, Gebreegziabher T, Lee HKM, Hui C.-W. Kinetic modelling and analysis of waste bamboo pyrolysis. Chemical Engineering Transactions. 2012;29:697702.

* Contribuição técnica ao $44^{\circ}$ Seminário de Redução de Minério de Ferro e Matérias-primas, $15^{\circ}$ Simpósio Brasileiro de Minério de Ferro e $2^{\circ}$ Simpósio Brasileiro de Aglomeração de Minério de Ferro, 15 a 18 de setembro de 2014, Belo Horizonte, MG, Brasil. 